\title{
ON THE POSITION OF SPATIAL AND TEMPORAL ADVERBIALS IN THE ITALIAN SENTENCE
}

\author{
Eva KLÍMOVÁ \\ University of Opava
}

\begin{abstract}
En): The article deals with the position of spatial and temporal adverbials in the Italian sentence from the functional sentence perspective (FSP) point of view, in comparison with English and Czech. Firstly, all the FSP factors are introduced, i.e. linearity, context, semantics, and, in the spoken language, intonation. The main attention is paid to semantics: spatial and temporal adverbials with the aim to prove that the position of these two sentence elements is closely related to their function on the Presentation scale and on the Quality scale. For this purpose more than 1500 clauses of an Italian text and its English translation have been analysed and statistically elaborated, with the aim to prove previous observations: a fairly strong tendency in Italian to organize the sentence elements in accordance with the basic distribution of communicative dynamism.
\end{abstract}

Résumé (Fr): Un résumé détaillé en français se trouve à la fin du texte.

Keywords (En): Spatial adverbial; temporal adverbial; position; semantic function; Presentation scale; Quality scale

\section{Introduction}

In the article entitled On Semantic Scales in Italian in comparison with English and Czech published in 2007 (KLÍMOVÁ, 2007b) the arrangement of sentence elements in Italian, in English and in Czech on the Firbasian semantic scales was observed and established in dependence on dynamic semantic functions that the sentence items may perform. The comparison between Italian, English and Czech was done with the aim to show the impact that the grammatical, i.e. morpho-syntactical rules of typologically different languages play not only in the process of the indication of dynamic semantic functions of a sentence item but also in the way in which along with semantics, other FSP factors, i.e. context, linear modification and in the spoken language intonation may manifest themselves. It is the interplay of these factors that determines the degree of communicative dynamism of a particular sentence element.

Now the intention is to concentrate on spatial and temporal adverbials in the Italian sentence, again in comparison with English and Czech. More precisely, the position of the spatial and temporal adverbials in the Italian sentence will be taken into consideration with the aim to prove that the position of these two sentence elements is closely related to their function on the Presentation scale and on the Quality scale. If the position of the spatial and temporal adverbials is to be considered some remarks on the linear modification of the sentence should be made first. Afterwards the schemes of the semantic scales and the functions of spatial and temporal adverbials in their implementation will be observed. For this purpose more than 1500 clauses of Alberto Moravia's novel Gli indifferenti and its English translation The Time of Indifference have been analysed and statistically elaborated, with the aim to prove previous observations included in the above mentioned article: a fairly strong tendency in Italian to organize the sentence elements in accordance with the basic distribution of communicative dynamism for which the basic rule is: the further towards the end of the sentence, the more 
the sentence element contributes towards the further development of the communication and the higher its degree of communicative dynamism.

\section{Word order of the Italian sentence in comparison with English and Czech}

In a language in which the word-order system consists in positioning the sentence elements in accordance with a gradual rise in CD a particularly strong tendency to collocate the rhematic element at the end of the sentence is observable: "The involvement of sentence linearity is borne out, for instance, by the fact that the element towards which the communication within a clause, independent or subordinate, is perspectived tends to occupy the final position" (FIRBAS, 1992 : 8). Comparing different word order systems two principles, considered by Mathesius and Firbas, must be mentioned: the grammatical principle, including the principle of grammatical function and the principle of coherence of members, and the FSP linearity principle.

In Italian the order $S$ - $V$ - $O$ is considered as unmarked from the syntactic point of view, nevertheless remarkable freedom may be observed in it. The deviations from $S-V-O$ word order are allowed especially by rich Italian verbal inflexion: Thanks to its inflexion the predicative verb is easily identified in the sentence and facilitates the identification of the grammatical subject. This is why the order $V-S$ is quite frequent here. Thus a strong tendency to Theme-Rheme sequence is observable in Italian word order dominated partially by the grammatical principle and partially by the FSP linearity principle.

In English the verbal inflection is almost zero. This is the reason why the identification of the predicative verb and hence of other sentence elements is extremely difficult. In fact it is almost exclusively the position that makes them recognisable (let us take a primitive example: work hard and hard work). The English word order $S-V-O$ is grammaticalized. In other words, it is the grammatical principle that plays the dominant role in its word-order system.

In Czech, thanks to abundant nominal and verbal inflexion the sentence elements are identified by their form and move within the sentence with a particularly strong tendency to place the rhematic element in the final position in the sentence, quite in correspondence with the basic distribution of communicative dynamism. It is the FSP linearity principle that plays the most important role here.

The example will demonstrate it $^{1}$ :

(1) E nei giorni normali nella vetrina era appeso un avviso ... GEN p. 29 And on ordinary days $a$ notice used to hang in the window ... Ve všední dny ve vitríně visela cedulka ...

DUB p. 3

The word order in the Italian and in the Czech version is the same: $A v v_{t}-A v v_{p^{-}}$ $V-S$ reflecting a gradual rise in $\mathrm{CD}:{ }^{2}$ Both adverbials, the temporal adverbial nei giorni normali/ve všední dny and the spatial adverbial nella vetrina/ve vitríně are

\footnotetext{
${ }^{1}$ For the examples 1-3 cf. KLÍMOVÁ (2007b). For the source and abbreviations of all the examples see the list following the bibliography.

${ }^{2}$ The abbreviation $A v v_{p}$ is used for the adverbial phrase of place and the abbreviation $A v v_{t}$ for the adverbial phrase of time.
} 
thematic. The rhematic subject un avviso/cedulka accompanied by the indefinite article in Italian occupies the final position in the Italian and the Czech version. In the English version the word order is $A v v_{t}-S-V-A v v_{p}$. The temporal adverbial on ordinary days occupies the initial position while the position of the spatial adverbial in the window is final. Yet it is thematic: it is the subject $\boldsymbol{a}$ notice that functions as rheme, being accompanied by the indefinite article as in Italian. Syntactically, the spatial adverbial is the complement of the verb and thus, obligatorily occupies the post-verbal position. Thus we may conclude that while in Italian and in Czech it is the FSP linearity principle to determine the position of the adverbial, in English it is the operation of the grammatical principle of coherence of members to determine it. ${ }^{3}$

\section{Semantic scales}

As mentioned above, the position of the spatial and temporal adverbials is closely related to the function that they have on the semantic scales, i.e. the Presentation scale and the Quality scale. For this purpose let me present the schemes of both scales with the dynamic semantic functions with respective communicative units:

In the scheme of the Presentation scale the dynamic semantic functions are:

\begin{tabular}{|c|c|c|c|c|c|}
\hline \multicolumn{3}{|c|}{$\begin{array}{l}\text { Scene/Setting } \\
\text { (Set) }\end{array}$} & $\begin{array}{l}\text { (Verb of) Presentation } \\
\text { on the scene (Pr) }\end{array}$ & \multicolumn{2}{|c|}{$\begin{array}{l}\text { Phenomenon } \\
\text { presented on the scene (Ph) }\end{array}$} \\
\hline (2) & $\begin{array}{l}C^{\prime} \\
\text { There } \\
\text { (Th) }\end{array}$ & $\begin{array}{l}\text { era } \\
\text { was } \\
\text { Tr }\end{array}$ & $\begin{array}{l}\text { un odore pesante } \\
\text { a heavy odour } \\
R h\end{array}$ & $\begin{array}{l}\text { nella stanza. } \\
\text { in the room. } \\
\text { Th }\end{array}$ & $\begin{array}{l}\text { GEN p. } 31 \\
\text { DUB p. } 6\end{array}$ \\
\hline & $\begin{array}{l}\text { V míst } \\
\text { Th }\end{array}$ & $\begin{array}{l}\text { byl } \\
\text { Tr }\end{array}$ & $\begin{array}{l}\text { těžká vưně. } \\
R h\end{array}$ & & \\
\hline
\end{tabular}

In sentence (2) in the Italian and in the English version the rhematic subject un odore pesantela heavy odour in the final position is the Phenomenon presented on the scene. The verb era/was is the transition and expresses Presentation on the scene. It is the adverb ci/there that allows the $\boldsymbol{V}-\boldsymbol{S}$ arrangement. It anticipates the thematic spatial adverbial nella stanza/in the room in the final position functioning as setting. In the Czech version the spatial adverbial $v$ mistnosti is observed at the beginning of the sentence. It should be added that while in English the word order $V-S$ is considered as usual only in the presentation structure there is/there are, in Italian it is quite normal in any sentence with a non-thematic subject (cf. example (1)).

In the scheme of the Quality scale the dynamic semantic functions are:

\footnotetext{
${ }^{3}$ For more details on linear modification in Italian in comparison with English and Czech see KLÍMOVÁ (2011), and for the interplay of factors see KLímOVÁ (2007a).
} 
(Scene/Setting) (Set) $\quad$ Quality bearer (B)
$\downarrow$
Theme (Th)

(3) Nel corridoio In the corridor V předsíni Th

$\begin{array}{lll}\text { incontrò } & \text { Michele } & \text { IND p. 12 } \\ \text { she met } & \text { Michele } & \text { TIM p. 12 } \\ \text { potkala } & \text { Michela } & \\ \text { Tr } & \text { Rh } & \end{array}$

\section{Specification(s) (Sp) \\ Rheme (Rh)}

Transition (Tr)

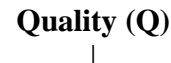

cheste

Michela
Rh

In sentence (3) the spatial adverbial nel corridoio/in the corridor/v predsini in the initial position functions as Scene. The subject, indicated by the personal suffix $-\grave{o} /-a$ in Italian and in Czech and by the pronoun she in English, functions as Quality bearer. It is, along with the Scene, thematic. The verb incontrò/met/potkala is the transition and its semantic function is that of Quality. The context independent object Michele in the final position is the rheme and its semantic function is that of Specification. It should be added that in case of the absence of Specification it is the verb that becomes the rheme of the sentence.

The arrangement of the scales reflects a gradual rise in $\mathrm{CD}$, i.e. from the item carrying the lowest to the item carrying the highest degree, in accordance with the basic distribution of $\mathrm{CD}$.

\section{The analysis of the material}

For the purpose of our observations about 1500 clauses of a written literary Italian text have been analysed. The position of temporal and spatial adverbials was considered with respect to the operation of several aspects: first of all with respect to their FSP function, but also with respect to other aspects, of which, and it is necessary to stress it, only the most significant will be taken into consideration in the following discussion.

The results of the analysis of the text are presented in the table below:

\begin{tabular}{|c|c|c||}
\hline & $\begin{array}{c}\text { SETTING } \\
\text { Initial/Final }\end{array}$ & $\begin{array}{c}\text { SPECIFICATION } \\
\text { Final }\end{array}$ \\
\hline Temporal adverbials & $82 / 7$ & 65 \\
\hline$\%$ & $\mathbf{9 2 / 8}$ & $\mathbf{1 0 0}$ \\
\hline & Phrasal/Clausal & Phrasal/Clausal \\
\hline & $76 / 13$ & $227 / 1$ \\
\hline Spatial adverbials & $31 / 19$ & 228 \\
\hline$\%$ & $\mathbf{6 2 / 3 8}$ & $\mathbf{1 0 0}$ \\
\hline
\end{tabular}

- The total number of Temporal adverbials functioning as setting is 89 , of which 82 in the initial and 7 in the final position. Of the total number of 89, 76 cases are phrasal, 13 are clausal.

- The total number of Spatial adverbials functioning as setting is 50, of which 31 in the initial and 19 in the final position. Within the category of temporal and spatial adverbials their phrasal realization was distinguished from the clausal one.

- The total number of Temporal adverbials functioning as Specification is 65 . 
- The total number of Spatial adverbials functioning as Specification is 228.

Let us remind ourselves that in Czech both temporal and spatial adverbials, both those functioning as setting and those functioning as specification, occupy the position that corresponds to the gradual rise of CD: settings exclusively in the initial position, specifications exclusively in the final position.

\section{Temporal adverbials}

The figures prove that the position of Temporal adverbials corresponds to its FSP function: if functioning as setting, they occupy the initial position, if functioning as specification, their position is final. Yet there are those 7 cases (see the table) in which the temporal setting was found in other than initial position. Let us have at least some examples:

(4) Capì di aver lasciato passare in quella serata mille occasioni,...

IND p. 30

He realized that, during that evening, he had already missed numberless opportunities..

TIM p. 26

Uvědomil si, že ten večer už promeškal bezpočet př́ležitostí, jak ...

In this case the initial position of the adverbial setting in the Italian version is impossible due to the operation of the grammatical principle of coherence of members: the non-finite clause aver lasciato passare cannot be separated from the preposition $d i$ which introduces it occupying the central position, like in the following sentence:

(5) ... gli parvero in quel momento ridicoli...

IND p. 31

..., they all seemed to him, at that moment, to be ridiculous,...

TIM p. 27

$V$ té chvíli se mu všichni zdáli směšní.

Though the position of the temporal adverbial in this sentence is not initial, its dynamic semantic function is evident: it is accompanied in both these examples by a determiner and thus indicated as Setting. Moreover, in the English version it is separated by commas. (See the Czech version with the temporal setting in the initial position.)

In another case, the final position of the temporal setting is due to the operation of the context, as in the sentence:

(6) (E ti par nulla due giorni?) Si possono far tante cose in due giorni ". IND p. 14

(And does two days seem nothing to you?) One can do so many things in two days.

TIM p. 10

(A $d v a$ dny pro tebe nejsou nic?) Tolik věcí se dá udělat za dva dny.

The temporal adverbial in due giorni/in two days/za dva dny is a context dependent element. And thus the intonation centre is on the only context independent element tante cose/so many things/tolik věcí, here in the central position. 
As we have shown above, temporal specifications occupy in all the cases the final position. There is one case in which it is observed in the initial position due to the operation of the subjective word order:

(7) E' tanto tempo che lo porto.

I've been wearing it for a very long time.

Už je to dlouho, co ho nosím.
IND p. 13

TIM p. 9

Both in Italian and in Czech the temporal adverbial tanto tempo and dlouho occupies the initial position being stressed in its rhematic function in a cleft sentence (so called "frase scissa" in Italian). In the English version its position also in this case is grammaticalized, i.e. final.

\section{Spatial adverbials}

Spatial adverbials functioning as Specification always occupy the final position. What is surprising are the statistics concerning the position of the Spatial adverbials functioning as Setting: there are those 19 cases of Spatial setting in the final position. This fact is worth considering: These 19 case comprise clauses of which 14 represent a special type of Presentation scale. It presents a particular though quite common feature:

(8) Un'espressione delusa passò sul volto della madre. An expression of disappointment crossed her mother's face. Matčinou tváří se mihl výraz zklamání.
IND p. 23

TIM p. 20

The Italian and the English version have $S$ - $V$ arrangement with subject in $\mathrm{Ph}$ function accompanied by the indefinite article; in Czech order is $V-S$. The verbs passò/crossed/mihl se express the meaning of appearance implicitly yet quite clearly. The example (I cite) "has a context-independent subject presenting a phenomenon appearing on a human body, the element(s) expressing the body or some part of it performing the role of the setting". "Within the category of this special type of the Presentation scale there are remarkable differences between Italian and English: in 5 cases of 14, in English the sentence structure is different:

(9) Una leggera dolorosa impazienza la pungeva. She was afflicted with a slight but distressing impatience. Trýznila ji bolestná netrpělivost.
IND p. 11

TIM p. 10

While in the Italian version also in this case the arrangement is $S$ - $V$ with the rhematic subject in the initial position, in English the passive voice was used. Thanks to its employment, in English the linear arrangement observes a gradual rise in $\mathrm{CD}$. In this way also English tends to mitigate the operation of the grammatical principle which is often the obstacle of the basic distribution of CD.

The remaining 5 cases of the spatial setting in the final position comprise 2 cases representing the Presentation scale with the structure $c^{\prime} \grave{e}$, ci sono, 1 case of the Presentation scale with the rhematic subject in the initial position different

\footnotetext{
${ }^{4}$ FIRBAS $(1992: 60)$.
} 
from the 14 cases described above, and 2 cases in which the word order is under the operation of the principle of coherence of members. This survey points out to phenomena non existing in Czech.

In the following examples another aspect was taken into consideration: the punctuation. In the sentence:

(10) (... protestò Leo) posando su Lisa, tra il fumo del suo sigaro ${ }_{2}$ uno sguardo mistificatore; IND p. 32

the spatial adverbial tra il fumo del suo sigaro is inserted between two complements of the verb posare, i.e. spatial adverbial su Lisa and the direct object uno sguardo mistificatore, and separated from them by a comma. Thus it has parenthetical status and does not work counter the principle of the coherence of members, according to which the verb and its complements are inseparable. It functions as setting, irrespective of its sentence position. Similarly in the sentence:

(11) tra quei due, Leo e Lisa, c'era stata una relazione, un amore, molti anni prima, ...

IND p. 37

the temporal adverbial molti anni prima, being separated by commas from the preceding elements, has the function setting, irrespective of the final position. It is the context independent subject un amore that functions as rheme.

\section{Conclusions}

The statistics prove that the position of the spatial and temporal adverbials in the Italian sentence corresponds to their dynamic semantic function on the semantic scales and confirm the tendency to organize the sentence elements in accordance with the basic distribution of communicative dynamism in the Italian word-order system. A tendency towards the operation of the grammatical principle may be registered where the position of certain elements is grammaticalized, i.e. dominated by a grammatical rule. This is especially the case of the $S$ - $V$ arrangement in the implementation of the Presentation scale with the grammatical subject accompanied by the indefinite article in Ph-function as in English, with the Spatial setting in the final position. It is the operation of Semantics that in spite of the linear arrangement determines the distribution of $\mathrm{CD}$.

\section{BIBLIOGRAPHY}

ADAM Martin (2011), On some specific FSP features of presentation scale sentences in the Gospel of Luke, in: ČERNÝ, CHAMONIKOLASOVÁ, KAVKA, KLÍMOVÁ, 2011, p. 9-17.

ANTINUCCI Francesco, CINQUE Guglielmo (1977), Sull'ordine delle parole in italiano: l'emarginazione, Studi di grammatica italiana 6, Firenze, p. 121-147.

BENINCÀ Paola, SALVI Giampaolo, FRISON Lorenza (1991), L'ordine degli elementi della frase e le costruzioni marcate, in: RENZI, p. 115-225. 
ČERnÝ Miroslav, ChamonikolasovÁ Jana, KAVKa Stanislav J., KLÍMOVÁ Eva (2011), New Chapters in Functional Syntax, Ostrava, Ostravská univerzita.

DANEŠ František (1964), A Three-Level Approach to Syntax, Travaux Linguistique de Prague l, p. 225-240.

FIRBAS Jan (1964), From comparative word-order studies, Brno Studies in English 4, p. 111-128.

FIRBAS Jan (1966), Non-thematic subjects in contemporary English, Travaux Linguistique de Prague 2, p. 239-256.

FIRBAS Jan (1979), A functional view of 'ordo naturalis', Brno Studies in English 13 , p. 29-59.

FIRBAS Jan (1991), Il funzionamento del dinamismo comunicativo nella prospettiva funzionale della frase, in: SoRNICOLA, SvobODA 1991, p. 194209.

FIRBAS Jan (1992), Functional sentence perspective in written and spoken communication, Cambridge, Cambridge University Press.

Chamonikolasová Jana (2005), Dynamic semantic scales in the theory of functional sentence perspective, in: Aleg(r)ace pro Evu. Papers in Honour of Eva Hajičová, p. 61-67.

KLÍMOVÁ Eva (2002), Ordinamento lineare dell'enunciato in italiano, Linguistica Pragensia XII/1, p. 40-49.

KLÍMOVÁ, Eva (2003), Italské určité sloveso z pohledu funkční větné perspektivy ve srovnání s určitým slovesem anglickým, Opava, Slezská univerzita.

KLímová Eva (2004), Verbo italiano ed il verbo inglese sulle scale semantiche, Linguistica Pragensia XIV/1, p. 32-41.

KLÍMOVÁ Eva (2007a), Fattori della prospettiva funzionale dell'enunciato in italiano a confronto dell'inglese e del ceco, in: In onore di Ivan Seidl, Opava, Slezská univerzita, p. 113-123.

KLÍMOVÁ Eva (2007b), Osservazioni sulle scale semantiche in italiano a confronto dell'inglese e del ceco. Écho des études romanes III/1-2, České Budějovice, p. 173-181.

KLÍMOVÁ Eva (2011), From Comparative Word Order Studies: Thoughts on Word Order in Italian in Comparison with English and Czech. In: ČERNÝ, ChamoniKolasová, KavKa, KLÍmOVÁ, 2011, p. 28-46.

LONZI Lidia (1974), L'articolazione presupposizione-asserzione e l'ordine V-S in italiano. In: Fenomeni morfologici e sintattici nell'italiano contemporaneo, Roma, p. 197-215.

LONZI Lidia (1986), Pertinenza della struttura Tema-Rema per l'analisi sintattica.. In: Stammerjohann, p. 99-120.

MATHESIUS Vilém (1939), O tak zvaném aktuálním členění větném. Slovo a slovesnost 5, p. 171-174.

MATHESIUS Vilém (1942), Ze srovnávacích studií slovosledných, Časopis pro moderní filologii, 28, p. 181-190.

RENZI Lorenzo, (ed., 1991), Grande grammatica italiana di consultazione, vol. I, Bologna, Mulino.

SoRniCOLA Rosanna, SvobodA Aleš (eds.) (1991), Il campo di tensione, Napoli, Liguori.

STAMMERJOHANN Hans (ed) (1986), Tema-Rema in Italiano, Tübingen. 
SvOBODA Aleš (1989), Kapitoly z funkční syntaxe, Praha, SPN.

SvOBODA Aleš (1991), Le posizioni nell'ordine delle parole ceco dal punto di vista dell'articolazione attuale. In: SORNICOLA, SVOBODA, 1991, p. 423-452.

SvobodA Aleš (2005), Firbasian Semantic Scales and Comparative Studies, in: ČERMÁK Jan et al. (eds.) Patterns (A Festschrift for Libuše Dušková), Praha, Filozofická fakulta Univerzity Karlovy, p. 217-229.

\section{Texts used in examples}

JOYCE James (1992), Dubliners, London, Penguin Books. [Abbreviation DUB]

JoYCE James (1995), Gente di Dublino, (translation by Marina Emo Capodilista), Trento, Luigi Reverdito Editore. [Abbreviation GEN]

MORAVIA Alberto (1992), Gli indifferenti, Milano, Tascabili Bompiani. [Abbreviation IND]

MORAVIA Alberto (1975), The Time of Indifference, (translation by Angus Davidson), Frogmore, Panther. [Abbreviation TIM]

\section{RÉSUMÉ EN FRANÇAIS}

Renouant avec l'étude intitulée On Semantic Scales in Italian in comparison with English and Czech (2007), le présent article traite le problème de la position des compléments circonstantiels de lieu et de temps considérée du point de vue de la perspective fonctionnelle de la phrase (PFP). Pour ce faire, nous présentons d'abord les facteurs de la PFP, c'est-à-dire la linéarité, le contexte, la sémantique et, pour la langue parlée, l'intonation. Notre attention est consacrée particulièrement à la comparaison de l'organisation linéaire de la phrase italienne, anglaise et tchèque; cette comparaison aboutit à la constatation que l'ordre des mots, déterminé par le principe grammatical en anglais et par le principe de la PFP en tchèque, est influencé, en italien, conjointement par les deux principes. Par la suite, nous examinons les compléments circonstantiels de lieu et de temps dans un énoncé italien pour démontrer que leur position est liée à leur fonction sur les échelles sémantiques de Firbas. Sur l'échelle sémantique présentationnelle (Presentation Scale), les compléments circonstantiels correspondent à la fonction de la scène, pour ce qui est du temps et du lieu, et représentent par la suite le thème; par contre, sur l'échelle qualitative (Quality Scale), ils peuvent représenter, suivant le contexte, la scène avec la fonction du thème, ou la spécification avec la fonction du rhème. Au cours de l'étude, nous avons analysé et traité statistiquement plus de 1500 phrases tirés du roman Gli indifferenti d'Alberto Moravia pour les comparer avec la traduction anglaise. L'analyse et la comparaison doivent confirmer les observations faites précedemment: l'italien fait preuve d'une forte tendance à ordonner les éléments de la phrase conformément à la disposition de base du dynamisme communicatif, c'est-à-dire en commençant par l'élément qui a le plus bas degré du dynamisme communicatif pour terminer par l'élément qui en possède le degré le plus haut. La statistique prouve que la position des compléments circonstantiels de lieu et de temps dans la phrase italienne correspond à leur fonction sur l'échelle sémantique. L'influence du principe grammatical et, par la suite, la perturbation de la disposition de base du dynamisme communicatif peut être observée dans le cas de la position préverbale 
du sujet rhématique et, en même temps, de la position finale du complément circonstantiel avec la fonction de scène sur l'échelle présentationnelle, semblablement à l'anglais. Il s'agit d'une preuve de l'interaction des facteurs de la PFP. 